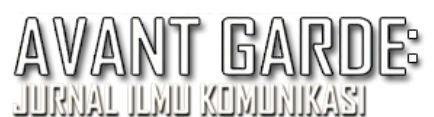

j-JSSN: 2338-431\%

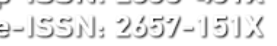

\title{
Strategi Komunikasi Dosen Dan Mahasiswa Dalam Meningkatkan Kualitas Pembelajaran Daring Selama Pandemik Covid-19
}

\author{
Nawiroh Vera \\ Nawiroh.vera@budiluhur.ac.id \\ Universitas Budi Luhur, Jalan Ciledug Raya, Petukangan Utara, Jakarta, Indonesia
}

Submitted: 02 November 2020 Revised: 25 November 2020 Accepted : 29 November 2020

\begin{abstract}
Abstrak
Penelitian ini bertujuan untuk menganalisis dan menjelaskan strategi komunikasi dosen dan mahasiswa dalam mengatasi hambatan dan kejenuhan mengikuti kuliah daring pada mata kuliah Teori Komunikasi. Pendekatan penelitian adalah kualitatif dengan metode studi kasus, yang melibatkan seorang dosen pengampu dan 45 mahasiswa kelas Teori Komunikasi. Hasil penelitian menunjukkan bahwa selama kuliah daring kecenderungan mahasiswa merasa bosan dan mengalami gegar budaya dalam proses belajar. Untuk mengatasi hal tersebut dosen menerapkan komunikasi dua arah, memberi kesempatan kepada mahasiswa untuk merespon balik berupa pertanyaan, diskusi, dan komentar atas apa yang disampaikan oleh dosen. Dosen memposisikan diri sebagai motivator dan inisiator dengan mengedepankan komunikasi yang berbudi luhur serta mampu menjadi pendengar yang baik, dan menjadi yang pertama memberi inisiatif, sehingga mahasiswa berani menyatakan pendapat secara aktif. Yang tak kalah penting dosen dan mahasiswa harus aktif, kreatif dan inovatif. Strategi komunikasi yang tepat yaitu komunikasi dua arah dengan menerapkan sistem pembelajaran problem base learning dan project base learning terbukti dapat menghilangkan kejenuhan dalam kuliah daring yang akhirnya dapat meningkatkan kualitas pembelajaran.
\end{abstract}

Kata kunci: belajar daring, kualitas pembelajaran, strategi komunikasi

\section{Communication Strategies between Lecturer and Student to Improving the Quality of Online Learning During the Covid-19 Pandemic}

\begin{abstract}
The purpose of this study was to analyze the communication strategies of lecturers and students in overcoming obstacles and boredom in online learning in the Communication Theory course. The research approach is qualitative with the case study method, the informant is a lecturer and 45 students of Communication Theory class. The results showed that during online lectures students tended to feel bored and get a culture shock in the learning process. To overcome this, the lecturer implements two-way communication, giving students the opportunity to respond either in the form of questions, discussions, and comments on what is conveyed by the lecturer. Lecturers position themselves as motivators and initiator by promoting polite communication, being able to be good listeners, and being the first to take the initiative, so that students dare to express opinions actively. it also needs to be the attention of lecturers and students to be active, creative and innovative. The right communication strategy is a two-way communication by implementing a problem-based learning system and a learning base project are proven to be able to eliminate boredom in online lectures which in turn can improve the quality of learning.
\end{abstract}

Key words: communication strategy, online learning, quality of learning 


\section{PENDAHULUAN}

Setelah WHO mengumumkan Covid19 sebagai pandemi global, maka Pemerintah Indonesia melalui kementerian pendidikan dan kebudayaan mengeluarkan surat edaran/instruksi kepada sekolah dan Universitas untuk melakukan proses belajar-mengajar di rumah yang disebut sebagai belajar di rumah (study from home).

Pada tahun 2018 Menteri Riset, Teknologi dan Pendidikan Tinggi, Muhammad Nasir, mendorong perguruan tinggi dalam negeri untuk mulai menerapkan perkuliahan jarak jauh secara daring atau online. Hal ini menjadi salah satu langkah yang harus ditempuh untuk bersaing di era revolusi industri sekaligus memberi kesempatan bagi lebih banyak orang untuk memperoleh akses ke pendidikan tinggi. Universitas Budi Luhur (UBL) segera merespon dorongan dan anjuran pemerintah dengan mulai menerapkan blended learning dalam proses perkuliahan, dibawah Learning Management System (LMS) semua fakultas di UBL mulai melaksanakan blended learning yaitu tiga pertemuan selama satu semester dilaksanakan secara daring (online).

Karena pandemi Covid-19, universitas telah ditutup dan belum tahu berapa lama ini akan berlangsung. E-learning menjadi sangat penting. Dosen telah diminta untuk menyelesaikan silabus mereka dan terus mengajar, dan melaksanakan ujian, dari jarak jauh. Muncul pertanyaan dalam diri peneliti, apakah dosen dan mahasiswa siap menghadapi situasi seperti ini? Beralihnya perkuliahan tatap muka menjadi kuliah daring tentunya memerlukan proses adaptasi yang tidak sederhana. Dosen dan mahasiswa dituntut untuk mempelajari cara menggunakan metode belajar online atau e-learning, juga harus dapat menggunakan platform rapat seperti zoom atau skype, google meet, dan sejenisnya.

Belum lagi tantangan lain untuk diatasi. Beberapa mahasiswa tanpa akses internet yang dapat diandalkan untuk berpartisipasi dalam pembelajaran online; kesenjangan ini terlihat di seluruh negeri, termasuk juga di Jakarta. Selain permasalahan dari segi teknologi, permasalahan lainnya yang tidak bisa diabaikan adalah masalah berkomunikasi antara dosen dan mahasiswa terutama dalam menyampaikan materi kuliah. Komunikasi dikatakan efektif jika antara pelaku komunikasi yaitu komunikator dan komunikan memiliki frame of reference dan field of experience yang sama.

Komunikasi adalah suatu transaksi, proses simbolik yang menghendaki orang-orang mengatur lingkungannya dengan membangun hubungan antar sesama manusia melalui pertukaran infomasi untuk menguatkan sikap dan tingkah laku orang lain serta berusaha mengubah sikap dan tingkah laku itu (Cangara, 2007). Everett M. Rogers dan Lawrence Kincaid (Wiryanto, 2004) menyatakan bahwa komunikasi adalah suatu proses di mana dua orang atau lebih membentuk atau melakukan pertukaran informasi antara satu sama lain, yang pada gilirannya terjadi saling pengertian yang mendalam. Mahasiswa dan dosen dalam mengembangkan jiwa kreatif harus selalu dinamis dalam berkomunikasi.

Pesan komunikasi idealnya dapat dipahami dengan baik oleh penerima, jika dalam proses perkuliahan tentunya pesan dimaksud adalah materi pembelajaran. Apakah semua mahasiswa dapat menerima materi dalam bentuk modul atau power point, seberapa besar pemahaman mereka tentang materi hanya dengan membaca? Bagaimana jika ada hal-hal yang belum dimengerti, apakah mahasiswa dapat memperoleh jawaban saat itu juga? 
Pertanyaan-pertanyaan inilah yang perlu dipecahkan agar suasana belajar dan mengajar semakin nyaman.

Pandemik Covid19 yang datang mendadak, dimana penerapan PSBB berdampak pada berbagai sektor kehidupan, salah satunya adalah perubahan proses belajar-mengajar dari tingkat dasar sampai perguruan tinggi. Banyaknya masalah yang muncul saat belajar online menjadi tantangan tersendiri bagi dosen dan mahasiswa dalam menjalakan tugas masingmasing, agar tujuan pembelajaran tetap tercapai, kualitas output tetap terjaga. Semua masalah dalam perkuliahan daring ini dapat terselesaikan jika dosen memiliki strategi dan gaya komunikasi khusus selama proses kuliah daring saat pandemic berlangsung. Dosen harus dapat menciptakan metode belajar yang kreatif dan inovatif, sedangkan mahasiswa dituntut untuk aktif dalam belajar. Student learning center saja tidak menjamin hasil maksimal. Lebih ideal lagi metode pembelajaran mensinergikan antara student learning center dengan teacher learning center ditambahkan pula kolaboratif learning dalam bentuk problem base learning dan project base learning.

Untuk menjawab permasalahan ini penulis tertarik untuk melakukan penelitian dengan judul "Strategi komunikasi dosen dan mahasiswa dalam meningkatkan kualitas pembelajaran selama pandemik Covid19". Penelitian ini diharapkan dapat memberi kontribusi berharga dalam menyikapi berbagai permasalahan di bidang pendidikan khususnya pendidikan tinggi di Indonesia dalam situasi dan kondisi khusus seperti saat ini.

Penelitian sejenis dengan tema penelitian ini pernah dilakukan oleh Mutawakkil \& Nuraedah tahun 2019 berjudul Gaya Komunikasi Dosen dalam Pembelajaran Mahasiswa. Gaya komunikasi berkaitan erat dengan proses pendekatan yang dilakukan dosen terhadap mahasiswa, masing-masing dosen memiliki strategi tertentu ketika melakukan komunikasi dalam perkuliahan. Masing-masing dosen memiliki pengetahuan dan pengalaman dalam melakukan proses perkuliahan, mereka juga memiliki indikator di luar panduan yang telah ditetapkan Perguruan Tinggi, sehingga akan berdampak pada perbedaan dan khas dosen dalam mentransfer ilmu pengetahuan. Hasil penelitian menunjukkan bahwa dalam mengatasi kejenuhan belajar, dosen mengembangkan gaya komunikasi aktif, namun tetap mengedepankan ketegasan, mengambil secara penuh inisiatif sosial agar mahasiswa dapat meniru, mampu mengintegrasikan dengan lingkungan sosialnya, mampu menyatakan pendapatnya secara emosional namun terkontrol, mengirim informasi dengan penuh perhatian.

Penelitian Rama Kertamukti (2013) berjudul Strategi Komunikasi Antarpribadi Dosen Dan Mahasiawa Dalam Pengembangan Jiwa Kreatif. Setiap orang dan setiap hubungan adalah unik. Apa yang benar atau berlaku pada sebagian besar orang atau kelompok tertentu belum tentu benar atau berlaku pada diri anda atau hubungan anda. Hubungan amtarpribadi merupakan hal yang hidup dan dinamis. Hubungan antarpribadi selalu berkembang, tidak pernah statis dan selalu berkembang. Strategi komunikasi antarpribadi yang diperlihatkan dosen dan mahasiswa di prodi Ilmu Komunikasi UIN Sunan Kalijaga dapat diperlihatkan seperti model yang dapat digambarkan. Pertama dosen mengadakan kontak dengan mahasiswa dengan menciptakan hubungan yang bersahabat, ramah, dan dinamis dalam menjumpai perbedaan dikedua belah pihak. Adanya keterlibatan dan keakraban dalam berhubungan, dosen selalu melibatkan secara aktif dalam penyelesaian ataupun sedang 
melakukan metode, sehingga dosen tidak merasakan formalitas. Hasil dari pola yang terbentuk adalah keakraban dosen dan mahasiswa yang dapat menciptakan jiwa kreatif dalam diri mahasiswa didukung kurikulum yang mengharapkan mahasiswa menjadi jiwa-jiwa kreatif untuk masa depan atau karier mereka nanti.

Kedua penelitian tersebut menjadi kajian literatur bagi peneliti, perbedaannya terletak pada model pembelajarannya, yaitu model tatap muka di kelas. Sedangkan penelitian ini fokus pada pembelajaran daring lebih khusus lagi selama masa pandemi Covid-19. Penelitian ini dilakukan pada masa awal pandemik sehingga peneliti belum menemukan kajian penelitian tentang pembelajaran daring selama covid.

Onong Uchjana Effendy menjelaskan bahwa strategi pada hakekatnya adalah perencanaan (planning) dan manajemen (management) untuk mencapai suatu tujuan. Tetapi untuk mencapai tujuan tersebut, strategi tidak berfungsi sebagai peta jalan yang hanya menunjukkan bagaimana taktik operasional (Effendy, 2013). Strategi adalah suatu seni, bukan sesuatu yang ilmiah, dan ada banyak cara pendekatan yang berbeda untuk melakukan sebuah strategi yang diperlukan. Begitu pun dalam berkomunikasi kita harus memiliki strategi yang cocok untuk menyampaikan pesan yang akan kita berikan kepada khalayak diluar sana. Pastinya strategi ini dilakukan untuk mencapai tujuan yang telah ditetapkan.

Strategi komunikasi mencakup segala sesuatu yang dibutuhkan untuk menjalankan program komunikasi kepada khalayak sasaran guna mencapai tujuan yang diharapkan. Strategi komunikasi dalam program komunikasi membutuhkan suatu cara yang cocok agar tujuan dari program itu tercapai (Widodo dan Permatasari, 2020). Merujuk pada artikel jurnal Communication Theory: An Underrated Pillar on Which Strategic Communication Rests yang ditulis oleh Betteke van Ruler: Strategi komunikasi "tidak boleh terbatas pada pesan formal, sementara tindakan juga mengandung arti dan, oleh karena itu, harus menjadi bagian dari komunikasi strategis." Proses komunikasi strategis biasanya adalah proses komunikasi yang mengikuti dari rencana strategis organisasi dan berfokus pada peran komunikasi dalam memungkinkan tujuan dan sasaran strategis organisasi." (Paul, 2011; Holtzhausen and Zerfass 2015). "Komunikasi strategis adalah praktik komunikasi yang disengaja dan bertujuan yang dilakukan oleh agen komunikasi di ruang publik atas nama entitas komunikatif untuk mencapai tujuan yang ditetapkan" (Holtzhausen \& Zerfass, 2013).

Strategi komunikasi merupakan paduan antara perencanaan komunikasi (communication planning) dengan manajemen komunikasi (communication management) untuk mencapai tujuan yang telah ditetapkan. Strategi komunikasi ini harus mampu dilakukan secara praktis (diterapkan dalam praktek) sesuai pertunjuk operasionalnya, dalam arti kata bahwa pendekatan dapat berbeda sewaktu-waktu bergantung pada situasi dan kondisi.

Strategi komunikasi dimaksud pada penelitian ini adalah strategi komunikasi dosen dalam menyampaikan materi kuliah khususnya dalam penelitian ini adalah mata kuliah Teori Komunikasi. Juga strategi komunikasi mahasiswa dalam menerima dan merespon materi, juga berdiskusi secara daring. Selama pandemik dimana perkuliahan dilakukan secara daring menggunakan metode belajar e-learning yang berbeda dari perkuliahan sebelum pandemik, dikhawatirkan mempengaruhi kualitas pembelajaran. Aspek-aspek inilah yang menjadi perhatian utama peneliti dalam menganalisis hasil penelitian. 
Menurut M. Ngalim Purwanto (dalam; Paryanto dkk, 2009) Kualitas pembelajaran dapat dilihat dari segi proses dan hasil proses pembelajaran. Dari segi proses, pembelajaran dikatakan berkualitas apabila seluruhnya atau setidak-tidaknya sebagian besar (75\%) peserta didik terlibat secara aktif baik fisik, mental maupun sosial, dalam proses pembelajaran disamping menunjukkan kegairahan belajar yang tinggi. Sedangkan dari segi hasil, proses pembelajaran dikatakan berhasil apabila terjadi perubahan perilaku yang positif pada diri peserta didik seluruhnya atau setidak-tidaknya Sebagian besar $(75 \%)$.

Salah satu faktor yang menentukan berhasilnya upaya meningkatkan kualitas kegiatan belajar mengajar, tidak terlepas dari prilaku dan gaya bicara seorang pengajar. Gaya bicara ini dapat dikaitkan dengan empat faktor yang harus ada pada pengajar (Danumihardja, 2014):

1. Pengetahuan (knowledge); Penguasaan materi sesuai dengan pengetahuan yang akan ditransfer kepada peserta didik tentu saja menjadi prasarat untuk tampil di depan kelas, sebab salah satu tugas pengajar adalah melakukan transfer of knowledge.

2. Ketulusan (Sincerity); pengajar baik guru atau dosen merupakan orang tua kedua bagi anak-anaknya oleh karena itu diperlukan ketulusan dalam membimbing setiap peserta didik, dengan demikian diharapkan akan terjadi perubahan prilaku pada setiap individu dengan semakin bertambahnya informasi yang didapat di sekolah. Ketulusan dalam melaksanakan tugas sebagai pengajar akan memperlancar jalannya proses belajar mengajar, karena secara tidak langsung pengajar akan bertanggungjawab terhadap materi yang disampaikan.

3. Antusias (Enthusiasm) ; Dalam menjalankan tugas dan perannya seorang guru atau dosen perlu melakukan tugas dengan penuh antusias, antusiasme ini akan mempengaruhi susana atau lingkungan kelas, apabila guru atau dosen masuk kelas dengan penuh antusias akan membawa dampak terhadap situasi kelas dan berpengaruh terhadap situasi belajar. Seorang pengajar yang antusias akan selalu kelihatan semangat dalam melaksanakan tugas, gembira dan selalu berfikiran positf dalam mengelola KBM, sebagai tugas dan tanggung-jawab sekaligus merupakan pekerjaan yang disenanginya. Sikap antusiasme ini harus tetap dipertahan dan tidak berubah menjadi super ego.

4. Latihan (Practice) ; Latihan perlu dilakukan oleh guru, sebab latihan yang rutin dilaksanakan akan meningkatkan ketrampilan guru atau dosen mengajar, hal ini berhubungan dengan guru sebagai profesi bukan saja sekadar memberikan informai, tetapi baik guru atau dosen dituntut untuk trampil menyampaikan informas, untuk itulah setiap guru atau dosen perlu setiap saat melatih diri untuk meningkatkan ketrampilan dalam bidang KBM.

Berdasarkan pengertian tentang kualitas pembelajaran yang dijelaskan maka dapat dikatakan bahwa kualitas pembelajaran dapat tercapai jika proses pembelajaran dilaksanakan secara sinergis, dengan menggunakan metode yang sesuai.

Dosen dan mahasiswa masing-masing harus berperan aktif dalam kegiatan belajar mengajar. Dosen dituntut melakukan kreativitas dlam mengajar, dosen dituntut untuk disiplin dan inovatif, dosen hendaknya selalu antusias dan tulus dalam mengajar, juga mengasah terus 
pengetahuan. Mahasiswa dituntuk untuk serius dalam belajar, aktif, meliki kesadaran dalam belajar mandiri, serta disiplin terutama dalam menyelesaikan tugas-tugasnya.

\section{METODE PENELITIAN}

Penelitian ini merupakan jenis penelitian kualitatif, menurut Cresswell (2018) qualitative research is an approach for exploring and understanding the meaning individuals or group ascribe to a social or human problem. the process of research involves emerging questions and procedures, data typically collected in the participant's setting, data analysis inductively building from particulars to general themes, and the researcher making interpretations of the meaning of the data. the final written report has a flexible structure. those who engage in this form of inquiry support a way of looking at research that honours an inductive style, a focus on individual meaning, and the importance of reporting the complexity of situation. (penelitian kualitatif adalah suatu pendekatan untuk mengeksplorasi dan memahami makna individu atau kelompok yang terkait dengan masalah sosial atau manusia. Proses penelitian melibatkan pertanyaan dan prosedur yang muncul, data yang biasanya dikumpulkan dalam setting partisipan, analisis data secara induktif dibangun dari hal-hal khusus hingga tema umum, dan peneliti membuat interpretasi tentang makna data. laporan tertulis akhir memiliki struktur yang fleksibel. mereka yang terlibat dalam bentuk penyelidikan ini mendukung cara memandang penelitian yang menghormati gaya induktif, fokus pada makna individu, dan pentingnya melaporkan kompleksitas situasi).

Penelitian ini menggunakan metode studi kasus. Pada dasarnya, metode penelitian merupakan cara ilmiah untuk mendapatkan data dengan tujuan dan kegunaan tertentu. Berdasarkan hal tersebut, terdapat 4 kata kunci yang perlu diperhatikan yaitu, cara ilmiah, data, tujuan dan kegunaan. Cara ilmiah berarti kegiatan penelitian itu didasarkan pada ciriciri keilmuan yaitu rasional, empiris dan sistematis (Sugiyono, 2014). Studi kasus berlaku apabila suatu pertanyaan "bagaimana" dan "mengapa" diajukan terhadap seperangkat peristiwa masa kini yang mustahil atau setidaknya sukar dikontrol oleh periset.

Metodologi studi kasus bisa digunakan jika:

1. Peneliti mempunyai informasi yang sedikit mengenai hal yang diteliti

2. Fokus penelitian adalah sebuah fenomena yang telah berlangsung

3. Ada banyak sumber data (Yin 2002)

Subjek penelitian ini adalah dosen dan mahasiswa, dalam hal ini peneliti sendiri selaku subyek penelitian dan mahasiswa Fakultas Ilmu Komunikasi Universitas Budi Luhur, yang mengambil mata kuliah Teori Komunikasi sebagai sasaran penelitian.

Penelitian ini menggunakan dua jenis sumber data yaitu data primer dan data sekunder. Data primer diperoleh melalui observasi partisipan selama perkuliahan, dan melalui wawancara mendalam terhadap mahasiswa yang mengikuti kuliah online mata kuliah teori komunikasi selama satu semester yaitu semester genap tahun akademik 2019/2020. Sedangkan data sekunder melalui kajian Pustaka dan literatur yang mendukung penelitian ini. 
Komunikasi dosen dengan mahasiswa secara efektif di dalam proses perkuliahan daring sangat diperlukan guna memperoleh hasil pembelajaran yang maksimal. Cara berkomunikasi baik dosen kepada mahasiswa maupun sebaliknya yaitu mahasiswa dengan dosen tentunya berbeda satu dengan yang lainnya. Masing-masing pelaku komunikasi memiliki strategi dan gaya yang berbeda. Perbedaan tersebut dapat dilihat dari latar belakang budaya, pengalaman, tingkat Pendidikan. Dosen dan mahasiswa sebagai aktor yang terlibat dalam pembelajaran daring dituntut memiliki kreativitas serta inovasi dalam proses perkuliahan ataupun belajar-mengajar agar meminimalkan hambatan pada kuliah daring.

Berdasarkan hasil observasi dan wawancara lapangan yang telah peneliti dapatkan pada kasus kuliah daring di Fakultas Ilmu Komunikasi Universitas Bbudi Luhur pada mata kuliah teori komunikasi. Terdapat beberapa masalah yang muncul pada mahasiswa selama satu semester kuliah daring, masalah tersebut antara lain, sulit memahami materi kuliah yang diberikan baik berupa modul maupun buku referensi. Teori komunikasi adalah mata kuliah yang agak membosankan bagi mahasiswa dan cukup melelahkan, karena mahasiswa dituntut banyak membaca. Selain itu untuk memahami sebuah teori kadang jika hanya dengan membaca agak sulit bagi mahasiswa dapat memahami, maka perlu penjelasan dari dosen. Padahal selama kuliah daring (e-learning), dosen mengunggah materi kuliah berupa modul dan diskusi dilakukan melalui forum secara online dimana tidak semua mahasiswa dapat mendengarkan dengan baik, terkadang kendala teknis seperti tidak stabilnya sinyal, atmosfir yang kadang mengganggu kejernihan suara seperti angin, hujan, kendaraan yang lewat, semua ini tentu sangat berpengaruh terhadap penerimaan mahasiswa.

Permasalahan lainnya adalah munculnya hambatan lain yaitu kejenuhan belajar. Kejenuhan belajar didefinisikan sebagai berikut "rentang waktu tertentu yang digunakan untuk belajar, tetapi tidak mendatangkan hasil. Kejenuhan belajar mengakibatkan mahasiswa tidak mampu menerima pelajaran bahkan tidak dapat memuat intisari dari pembelajaran tersebut" (Tohirin, 2009). Kejenuhan belajar merupakan hambatan dalam proses belajar, kejenuhan muncul karena mahasiswa mengalami gegar budaya dalam proses perkuliahan dari yang biasa tatap muka langsung di kelas, berubah menjadi online dimana mahasiswa diharuskan belajar mandiri dengan mempelajari modul.

Gegar budaya bisa diartikan sebagai keadaan dimana seseorang tidak mengenal kebiasaan sosial dari kultur baru, sehingga seorang individu tersebut tidak dapat menampilkan perilaku yang sesuai dengan aturan di lingkungan baru (Dayakisni \& Yuniardi, 2017 dalam Meizan, 2020). Gegar budaya atau culture shock merupakan reaksi emosi negatif yang dirasakan oleh individu ketika berpindah ke budaya baru yang sangat berbeda dengan budaya asalnya. Gegar budaya disebabkan oleh kurangnya pengetahuan dan pandangan negatif terhadap budaya barunya (Maizan et.al., 2020).

Gegar budaya dalam proses belajar mengajar merupakan kondisi dimana dosen memasuki atmosfir baru dalam mengajar sedangkan mahasiswa memasuki atmosfir baru dalam menerima materi pembelajaran, baik dosen dan mahasiswa memasuki babak baru proses pembelajaran yang masing-masing perlu beradaptasi. Proses adaptasi ini tentunya tidak bisa secara instan namun memerlukan waktu yang cukup panjang, selama proses inilah kejenuhan baik dari pengajar yang dalam hal ini dosen maupun peserta didik yaitu mahasiswa mulai muncul. 
Disini diperlukan kedisiplinan yang tinggi pada tiap mahasiswa, (student learning center). Gegar budaya tidak hanya terjadi pada mahasiswa, dosen juga mengalami gegar budaya, dosen harus beradaptasi dengan model belajar yang baru dengan mengandalkan pemahaman teknologi. Selain gegar budaya kejenuhan belajar yang dirasakan mahasiswa yaitu frustasi dengan keadaan yang dialami karena tidak dapat memahami materi yang diberikan. Kejenuhan memuncak setelah mereka merasakan tidak adanya kemajuan yang mereka rasakan. Menjawab soal latihan mereka merasa kesulitan. Hal ini senada dengan pendapat Hakim yang mengatakan "Kejenuhan belajar adalah kondisi mental seseorang saat mengalami rasa bosan dan lelah yang amat sangat sehingga mengakibatkan timbulnya rasa enggan, lesu dan tidak bersemangat melakukan aktivitas belajar" (Hakim, 2004). Untuk mengatasi hambatan-hambatan tersebut maka diperlukan strategi komunikasi dosen dan mahasiswa selama kuliah daring.

\section{Strategi Komunikasi dosen dan mahasiswa dalam meningkatkan kualitas pembelajaran}

Pengalaman mengajar daring mata kuliah Teori Komunikasi selama satu semester dosen berusaha semaksimal mungkin menggunakan beberapa strategi atau cara agar mahasiswa dapat memahami substansi dari teori-teori yang disampaikan. Dosen menggunakan multiple methode, yaitu modul dan buku, diskusi online, tanya jawab, kuis, dan tugas.

Strategi pertama adalah dosen merencanakan proses belajar sebaik-baiknya yang dapat membuat mahasiswa memahami materi, untuk itu bahan kuliah sudah harus ada, kuliah daring lazimnya menggunakan modul. Modul dirancang sesuai dengan kriteria belajar mandiri yang paling tidak terdiri dari; materi pokok, ringkasan materi, Latihan (kuis) harian beserta jawabannya, ini bertujuan agar mahasiswa dapat mengukur diri masing-masing seberapa pemahaman yang diperoleh dari materi pokok tersebut. Terakhir adalah test formatif berupa essay yang disesuaikan dengan setiap mata kuliah. Jika mata kuliah yang sifatnya praktek maka materi dapat ditambahkan berupa audio-visual, dengan melihat (menonton) langsung contoh kasus melalui video maka diharapkan mahasiswa menjadi lebih mengerti. Selain itu bentuk materi audio-visual dapat menjadi katarsis sehingga dapat mengurangi kejenuhan.

Strategi kedua yaitu manajemen komunikasi, manajemen disini adalah bagaimana dosen dan mahasiswa menerapkan disiplin belajar, yang perlu diperhatikan adalah masalah waktu, komitmen dosen dan mahasiswa, membuat rancangan capaian belajar, dan lain-lain yang disesuaikan dengan tiap mata kuliah.

Berdasarkan observasi dan wawancara kepada mahasiswa diperoleh jawaban beragam. Masalah jaringan (hambatan teknis) sering menjadi kendala, kadang mahasiswa sudah siap sesuai jadwal kuliah tetapi kadang terlambat, bahkan ada yang dipertengahan kuliah baru bisa gabung, ada juga dipenghujung kuliah baru masuk akibat kendala sinyal, dan sebagainya. Masalah ini tidak bisa dianggap ringan, karena secara psikologis mahasiswa takut tidak dianggap hadir oleh dosen, dianggap tidak disiplin, malas dan sebagainya. Disini diperlukan kebesaran hati dosen untuk tidak buru-buru berprasangka terhadap mahasiswa, dosen hendaknya membangun komunikasi yang kondusif dan bersedia mendengarkan alas an-alasan yang disampaikan mahasiswa. 
Dosen sudah semaksimal mungkin memandu jalannya pembelajaran, salah satunya melalui diskusi tatap muka online melalui beragam aplikasi yang tersedia. Namun tetap dituntut kreativitas dan inovasi yang bertujuan untuk membuat proses pembelajaran lebih menarik. Mata kuliah teori komunikasi diperuntukkan kepada mahasiswa semester kedua, dimana mahasiswa sendiri baru mulai beradaptasi dengan proses belajar di perguruan tinggi, gaya belajar sewaktu di SMA kadang masih terbawa. Berdasarkan wawancara yang peneliti lakukan terdapat beberapa pendapat mahasiswa selama kuliah daring, antara lain sebagai berikut:

"Saya lebih suka dosen menjelaskan materi dahulu, baru jika belum memahami saya membaca modul lebih serius dan juga buku referensi yang diberitahukan oleh dosen" "Lebih enak mendengar penjelasan dosen karena jika tidak mengerti bisa langsung bertanya saat itu juga. Apalagi jika dosen menambahkan penjelasan dengan contohcontoh kasus yang relevan"

Mereka lebih suka mendengarkan penjelasan langsung dari dosen terlebih dahulu, padahal di dalam sistem e-learning dosen memberikan modul sebagai materi pokok pembelajaran yang harus dibaca mahasiswa terlebih dahulu. Di sini terjadi perbedaan antara gaya mengajar dosen dengan yang diharapkan mahasiswa. Pada kasus ini dosen hendaknya secara bijaksana memberi arahan kepada mahasiswa tentang cara belajar jarak jauh yang baik dan benar.

Pendapat mahasiswa lainnya yaitu tidak semua mahasiswa berani mengeluarkan pendapat dengan bertanya, mereka khawatir dianggap bodoh oleh teman-temannya, ada juga yang khawatir dengan sikap dan gaya komunikasi dosen yang linier dan satu arah, tidak memberi kesempatan kepada mahasiswa untuk diskusi.

"Kadang mendengarkan dosen menjelaskan semakin saya bingung, suara tidak jelas, muncul hambatan teknis seperti sinyal yg tiba-tiba hilang, pokoknya semakin membuat kami menjadi stress dan muncul kejenuhan yang luar biasa. memahami materi saja belum berhasil, tetapi langsung diberi tugas, semakin pusing rasanya. Jika sudah demikian kami cukup online supaya dianggap hadir, setelah itu melakukan aktivitas lainnya, toh dosen tidak tahu apa yang kami lakukan di rumah"

Sesuai hasil pengamatan dan wawancara peneliti mengidentifikasi beberapa permasalahan pada kuliah dari Teori Komunikasi yaitu tidak terdapat persamaan cara belajar antara dosen dan mahasiswa, materi belajar yang membosankan, hambatan teknis dan hambatan komunikasi selama kuliah daring berlangsung. Yang paling mengkhawatirkan adalah munculnya kejenuhan belajar dan gegar budaya belajar. Beberapa faktor yang menyebabkan kejenuhan belajar adalah; cara mengajar dosen yang membosankan dan cenderung satu arah, materi sangat sulit dipahami, mahasiswa lelah karena banyaknya tugas. Pada kasus ini dosen diharapkan merubah gaya komunikasi selama belajar daring, komunikasi dua arah perlu terus diterapkan, jika mahasiswa pasif maka tugas dosen yang menstimuli agar mahasiswa Kembali aktif. Di sisi lain mahasiswa juga dituntut untuk merubah gaya belajarnya secara aktif.

Temuan lainnya yang peneliti pantau dari group whatsap yang dibuat oleh ketua kelas yang mana peneliti ada di dalam group tersebut, namun mahasiswa tidak mengetahuinya. Curhatan sesama mahasiswa dan keluh kesah kepada temannya terangkum sebagai berikut: 
"jujur gua itu sangat sulit jika harus membaca, teori pula pusing kepala gua, tolong dong bantu buatin tugas"

"gimana mau ngerjain tugas yang sangat teoritis padahal belum ngerti banget, pasrah aja deh mau dapat nilai berapa aja gua bersyukur yang penting lulus"

Jujur ya..man-teman aku itu orangnya agak lamban dalam menerima materi, aku lebih cepat ngerti jika langsung melihat contoh kasusnya secara langsung, apalagi elearning tambah sulit lagi, jadi rindu kuliah di kelas"

Dari berbagai ungkapan mahasiswa sebagai informan di atas, lalu dikaitkan dengan hasil observasi maka ditemukan fakta bahwa komunikasi dosen dan mahasiswa dalam pembelajaran online diperlukan strategi komunikasi dua arah secara maksimal, kecenderungan yang peneliti amati mahasiswa yang aktif bertanya, berkomentar di dalam forum chat online hanya beberapa orang dan hanya itu-itu saja personilnya. Dosen langsung merubah strateginya dengan memaksa mahasiswa pasif dengan memberi pertanyaan yang sederhana dahulu, tujuannya adalah untuk memancing keaktifan mereka. Ternyata ini cara seperti ini cukup berhasil. Mahasiswa merasa mendapat perhatian dari dosen, yang pada akhirnya membangkitkan semangat belajar pada diri mereka.

Dosen mengubah cara atau metoda dalam memberikan tugas dengan tidak meminta hasil yang sempurna, cukup membuat ringkasan dari materi tiap pertemuan walaupun hanya satu paragraf. Penilaian diutamakan dari segi orisinalitasnya, walupun jawaban belum maksimal. Dosen memberi penilaian saat itu juga di laman e-learning, ini bertujuan untuk menstimuli mahasiswa lebih aktif belajar. Nilai yang cepat diberikan ternyata membuat mahasiswa merasa bahwa jerih payahnya dihargai oleh dosen, dengan adanya nilai menunjukkan bahwa dosen membaca tugas mereka. Bentuk tugas lainnya yang mendapar respon positif dari mahasiswa adalah tugas kelompok yang harus dipresentasikan. Walaupun presentasi secara online, mereka menjadi bersemangat, kerinduan untuk tampil di depan teman-temanya terrealisasikan dengan tampilnya mereka dalam presentasi. Setiap anggota kelompok harus berbicara dan setiap peserta lainnya diharuskan bertanya. Baik yang bertanya maupun menjawab pertanyaan diberi nilai sebagai bentuk apresiasi.

Selanjutnya hasil observasi lainnya menunjukkan kejenuhan belajar teori komunikasi secara daring karena materi teori yang sangat sulit, dan metode pembelajaran yang kurang variatif, diperlukan strategi lain untuk mengurangi hambatan tersebut, misalnya diadakan kuis online, menampilkan contoh kasus merupa video agar mereka tidak jenuh. Dan mungkin perlu dikaji lebih dalam lagi strategi lainnya. faktor lainnya mahasiswa merasa perhatian dosen terhadap kejenuhan mereka kurang ditanggapi, maka jalan keluarnya adalah dosen merubah gaya komunikasi dalam mengajar dari yang tadinya satu arah menjadi dua arah, menghindari ketegangan dalam belajar, merubah gaya komunikasi yang dapat diterima mahasiswa, menciptakan situasi belajar yang santai sehingga terhindar dari ketegangan saat belajar.

Strategi colaboratif learning system dalam bentuk project base learning (PjBL) dan problem base learning ( $P B L)$ sudah saatnya dilakukan. PBL adalah salah satu model pembelajaran yang menempatkan siswa sebagai pusat pembelajaran. PBL mengajarkan siswa untuk berpikir kritis dan logis dalam memecahkan suatu masalah berdasarkan pengetahuan yang telah mereka miliki. "PBL akan mendorong siswa untuk mencari alternatif solusi dari 
masalah yang telah diberikan, kemudian siswa diminta untuk memilih solusi terbaik yang digunakan dalam memecahkan masalah yang ada. Sedangkan Model PjBL, siswa diminta untuk berpikir kritis dan ilmiah, dan juga menuntut siswa untuk belajar secara mandiri. Karena PjBL memberikan situasi belajar yang nyata bagi siswa, yakni siswa diminta untuk mengerjakan sebuah proyek yang nantinya akan memberikan pengetahun secara permanen. PjBL merupakan model pembelajaran dengan pendekatan konstruktivisme. Pendekatan ini menuntut siswa untuk belajar mandiri, dan dapat merencanakan dan melaksanakan pembelajarannya sendiri ataupun berkolabirasi dengan guru dan siswa yang lain (Lestari dan Juanda, 2019).

Dengan aktif dan kreatif dosen maupun mahasiswa diharapkan kuliah daring dapat membuahkan hasil yang berkualitas sesuai yang diharapkan dalam capaian pembelajaran. Selain itu sistem belajar kolaboratif dapat mengurangi kejenuhan dalam proses kuliah daring. Materi, tugas, diskusi, ujian, dibuat Bersama antara dosen dan mahasiswa. Bahkan mahasiswa sendiri yang membuat soal ujian dan dia sendiri yang harus menjawab, dosen menilai dari kreativitas mahasiswa membuat soal dan menemukan inovasi dari jawabannya.

\section{SIMPULAN}

Berdasarkan hasil penelitian menunjukkan bahwa strategi komunikasi dosen dan mahasiswa selama melaksankan kuliah daring sangat penting dilakukan, terutama untuk mengurangi gegar budaya dan kejenuhan dalam mengikuti perkuliahan. Untuk itu diperlukan langkah-langkah strategis : 1) Dosen hendaknya berupaya mengoptimalkan proses kuliah daring secara kreatif, variatif, dan inovatif, sehingga dapat menumbuhkan semangat belajar mahasiswa. Variasi materi yang tidak hanya mengandalkan modul, namun ditambah dengan materi audio-visual terbukti dapat mengurangi kejenuhan pada mahasiswa; 2) Menerapkan komunikasi dua arah, memberi kesempatan kepada mahasiswa untuk merespon baik berupa pertanyaan, diskusi, dan komentar atas apa yang disampaikan oleh dosen. Dosen memposisikan diri sebagai motivator dengan mengedepankan komunikasi yang berbudiluhur mampu menjadi pendengar yang baik, dan menjadi yang pertama memberi inisiatif, sehingga mahasiswa berani menyatakan pendapat secara aktif; 3) Mahasiswa perlu perhatian dari dosen, hal kecil seperti membalas email, membalas whatsap membuat mereka merasa diperhatikan, jika memberi tugas hendaklah segera diberi nilai atau setidaknya dberi komentar, dengan demikian mahasiswa merasa terstimuli karena apa yang dikerjakan tidak sia-sia.

\section{UCAPAN TERIMA KASIH}

Penulis mengucapkan terima kasih dan penghargaan yang setinggi-tingginya kepada reviewer dan editor yang telah menelaah dan mereview artikel ini. Terima kasih juga penulis hatur kepada tim redaksi Jurnal Avant Garde yang telah memberi masukan dan arahan hingga artikel ini diterima dan diterbitkan.

\section{DAFTAR PUSTAKA}


Betteke van Ruler. Communication Theory: An Underrated Pillar on Which Strategic Communication Rests. ISSN: 1553-118X (Print) 1553-1198 (Online) Journal homepage: https://www.tandfonline.com/loi/hstc20

Cangara, Hafied. (2007). Pengantar Ilmu Komunikasi, Jakarta: PT Raja Grafindo Persada. Creswell, John W., Creswell, J. David. (2018). Research design; Qualitative, Quantitative, and mix Methods Approches fifth edition. Los Angeles: Sage Publishing.

Danumihardja, Mintarsih. Meningkatkan Kualitas Pembelajaran Melalui Delapan Kebiasaan Dalam Pendidikan Matematika. Jurnal Euclid, ISSN 2355-17101, 2014. vol.1, No.1, pp. $1-59$

Effendy, Onong Uchjana. (2013). Ilmu Komunikasi Teori Dan Praktek. Bandung: Remaja Rosdakarya

Hakim, T. (2004). Belajar Secara Efektif. Jakarta: Puspa Swara

Holtzhausen, D. R., \& Zerfass, A. (2013). Strategic communication-Pillars and perspectives on an alternate paradigm.In K. Sriramesh, A. Zerfass, \& J.-N. Kim (Eds.),Current trends and emerging topics in public relations andcommunication management(pp. 283-302). New York, NY: Routledge.

Kertamukti, Rama. Strategi Komunikasi Antarpribadi Dosen dan Mahasiswa dalam Pengembangan Jiwa Kreatif (Studi Deskriptif pada program studi ilmu komunikasi UIN Sunan Kalijaga). Jurnal Komunikasi PROFETIK. Vol. 06, No. 2, Oktober 2013

Lestari, Isnania dan Raja Juanda. Komparasi Model Pembelajaran Problem Based Learning dan Project Based Learning Terhadap Hasil Belajar Siswa Pada Materi Perangkat Keras Jaringan Internet Kelas IX SMP Negeri 5 Sungai Kakap Kabupaten Kubu Raya. Jurnal Efektor, Volume 6 Issue 2, 2019, Pages 127 - 135. Available online at: http://ojs.unpkediri.ac.id/index.php/efektor-e

Maizan, Sabrina Hasyyati, Khoiruddin Bashori, Elli Nur Hayati. Analytical Theory: Gegar Budaya (Culture Shock). PSYCHO IDEA, Tahun 18.No.2, Agustus 2020, ISSN 2654-3516 (online)

Mutawakkil \& NuraedahGaya Komunikasi Dosen dalam Pembelajaran Mahasiswa. Communicatus: Jurnal Ilmu Komunikasi Volume 3 Nomor 2 (2019) 25-42

Tohirin. (2009). Psikologi Pembelajaran Agama Islam. Jakarta: PT. Raja Grafindo Persada. Paryanto,Widarto, Syukri FAW. Peningkatan Kulaitas Pembelajaran Mata Kuliah Bimbingan Kejuruan Melalui Implementasi Multi Strategi Belajar. 2009. http://staffnew.uny.ac.id/upload/131808327/penelitian.

Sugiyono. (2014). Metode Penelitian Pendidikan Pendekatan Kuantitatif, Kualitatif dan $R \& D$. Bandung: Alfabeta

Widodo, Aan, dan Diah Ayu Permatasari. Strategi Komunikasi Pemerintah Kota Bekasi Dalam Program Bekasi Sity. https://ejournal.unida.gontor.ac.id/index.php/ettisal

Wiryanto, (2004). Pengantar Ilmu Komunikasi. Jakarta: PT. Grasindo.

Yin, Robert K., (2002). Studi Kasus: Desain dan Metode. Jakarta: PT. Raja Grafindo Persada Sumber online :

http://dx.doi.org/10.21111/ejoc.v5i1.3454. Vol. 5, No.1, June 2020 
https://doi.org/10.29407/e.v6i2.13159 